\title{
El hilo de la fábula
}

Revista anual del Centro de Estudios Comparados

Facultad de Humanidades y Ciencias

Universidad Nacional del Litoral

\section{Diecisiete}

2017, Santa Fe, República Argentina

ISSN 1667-7900 


\section{El hilo de la fábula}

El hilo que la mano de Ariadna dejó en la mano de Teseo (en la otra estaba la espada) para que éste se ahondara en el laberinto $y$ descubriera el centro, el hombre con cabeza de toro o, como quiere Dante, el toro con cabeza de hombre, y le diera muerte y pudiera, ejecutada la proeza, destejer las redes de piedra y volver a ella, su amor.

Las cosas ocurrieron así. Teseo no podía saber que del otro lado del laberinto estaba el otro laberinto, el del tiempo, y que en un lugar prefijado estaba Medea.

El hilo se ha perdido: el laberinto se ha perdido también. Ahora ni siquiera sabemos si nos rodea un laberinto, un secreto cosmos, o un caos azaroso. Nuestro hermoso deber es imaginar que hay un laberinto y un hilo. Nunca daremos con el hilo: acaso lo encontramos y lo perdemos en un acto de fe, en una cadencia, en el sueño, en las palabras que se llaman filosofía o en la mera y sencilla felicidad.

Cnossos, 1984.

J.L. Borges. Los Conjurados, 1985.

A Dina San Emeterio, in memoriam. 